MARCin ChOCZYŃSKI

Cardinal Stefan Wyszyński Universityin in Warsaw, Poland

m.choczynski@uksw.edu.pl

ORCID iD: https://orcid.org/ 0000-0002-6636-9025

ARTUR WYSOCKI

Cardinal Stefan Wyszyński Universityin in Warsaw, Poland

a.wysocki@uksw.edu.pl

ORCID iD: https://orcid.org/ 0000-0002-8653-0314

\title{
A CASE STUDY OF A CONVENTIONAL PILOT ON RESEARCHING THE TRANSMISSION OF NATIONAL CULTURE IN THE ENVIRONMENT of Polish parishes in France
}

\author{
STUDIUM PRZYPADKU PILOTAŻU \\ KONWENCJONALNEGO DOTYCZĄCEGO BADAŃ \\ PRZEKAZU KULTURY NARODOWEJ W ŚRODOWISKU \\ POLSKICH PARAFII WE FRANCJI
}

\begin{abstract}
The subject of this article is the characteristics of the pilot study as such and their reference to the actually conducted research process - a CAWI-type (Computer Assisted Web Interview) analysis devoted to the French Polish diaspora and its opinion on the intertwining of religious and national culture. The research in question was based on the idea of conventional pilotage, which primarily defined the understanding of the questions by the respondents (including determining the scale of the lack of answers to specific questions, transitions between questions and instructions for the respondents). Reflection on the introduced research tool will show its usefulness in the empirical environment, as well as effectiveness and adaptation to the attitudes of respondents. The aim of the article is to show the 'work' of a research tool in a specific environment, also to show its potential strengths and weaknesses. The research conclusions focus on the sensitivity of the issues raised and the incompatibility of the questionnaire's tool with the level of general knowledge of the respondents, the language they use or the general cultural resource. This text is also a contribution to the development of in-depth pilot analyzes.
\end{abstract}




\section{STRESZCZENIE}

Tematem niniejszego artykułu są cechy badania pilotażowego jako takiego i ich odniesienie do faktycznie przeprowadzonego procesu badawczego - analizy typu CAWI (ang. computer assisted web interview) poświęconej Polonii francuskiej i jej opinii na temat przeplatania się kultury religijnej oraz kultury narodowej. Przedmiotowe badanie oparto na idei pilotażu konwencjonalnego, określającego przede wszystkim zrozumienie pytań przez respondentów (m.in. ustalenie skali braku udzielonych odpowiedzi na konkretne pytania, stosowania się przez ankietowanych do reguł przejścia między pytaniami i postępowania według instrukcji). Refleksja nad użytym narzędziem badawczym wykaże jego przydatność w środowisku empirycznym, a także efektywność oraz dopasowanie do postaw respondentów. Celem artykułu jest ukazanie „pracy” narzędzia badawczego w określonym środowisku oraz wykazanie jego potencjalnych mocnych i słabych stron. Wnioski badawcze ogniskują się wokół drażliwości poruszanych zagadnień oraz niezgodności narzędzia kwestionariusza z poziomem wiedzy ogólnej badanych, stosowanym przez nich językiem, a także ogólnym zasobem kulturowym. Niniejszy tekst jest ponadto przyczynkiem do rozwinięcia analiz pilotażu pogłębionego.

KEYWORDS: sociological research, pilot study, main study, testing the research tool, conventional pliot, in-depth pilot.

SŁOWA KLUCzowe: badanie socjologiczne, pilotaż, badanie zasadnicze, testowanie narzędzia badawczego, pilotaż konwencjonalny, pilotaż pogłębiony.

\section{WPROWADZENIE - ROLA I ZADANIA BADAŃ PILOTAŻOWYCH}

Truizmem jest twierdzenie o ważności i doniosłości badań pilotażowych, spełniających kilka ważnych funkcji, przede wszystkim tych odnoszących się do testowania narzędzi i określenia ram empirycznych procesu. Znaczenie badania pilotażowego jest zatem kluczowe z punktu widzenia pomyślności całego badania, a wnioski i rekomendacje dotyczące ,pracy” narzędzia badawczego w warunkach środowiskowych powinny owocować jego ulepszeniem (Smith, 2019, s. 592). Oprócz walidacji narzędzia badawczego, pośrednim celem niniejszego tekstu jest także podstawowa analiza wyników badania pilotażowego przeprowadzonego w 2019 r. na niereprezentatywnej próbie Polonii francuskiej należącej do polskich środowisk parafialnych. 
Warto dodać, że mimo iż rozważanie zagadnień badań pilotażowych posiada w polskiej socjologii dość długą tradycję (np. Przeworski, 1966, s. 281), to jednak badania pilotażowe nie są obecnie zbyt popularnym tematem odniesień, zatem każda próba ich analizy wydaje się działaniem niejako promującym ideę ich zastosowania.

Słowo ,pilot” posiada w języku potocznym wiele znaczeń. Oprócz typowo użytkowego zastosowania, na określenie człowieka kierującego statkiem powietrznym czy też przewodnika turystycznego, pilotem może być też rzecz - programator telewizora lub jakiegokolwiek innego urządzenia. Także w różnego rodzaju wyścigach, rajdach (kolarskich czy samochodowych) można zaobserwować występowanie pilota nadzorującego przebieg trasy. Pilotowanie należy zatem do kluczowych czynności w szeroko pojętym ruchu turystycznym oraz transporcie (np. przewożenie ponadwymiarowych gabarytów) czy też w kierowaniu żeglugą morską lub rzeczną (Dubisz, 2003a, s. 142). Ta główna funkcja pilota, czyli wskazywanie, określanie, podążanie, znalazła również zastosowanie w socjologii jako nazwa wstępnego badania, „rozgrzewki”, „testu” przed przeprowadzeniem właściwej analizy. Od czynności przypisywanych pilotowi - czyli umiejętności pilotażu - zapożyczono to wyrażenie, włączając je do metodologii socjologicznej. Ów „pilotaż”, wedle znaczenia słownikowego, ma przede wszystkim za zadanie weryfikację wiarygodności narzędzia badawczego przed zasadniczą analizą (Dubisz, 2003b, s. 142-143). Można powiedzieć, że to zadanie sprowadza się w praktyce do przeprowadzenia badacza społecznego przez środowisko respondentów lub rozmówców, a przy okazji do wskazania zarówno zalet, jak i niedomagań zastosowanego narzędzia.

Metodologia socjologiczna na przestrzeni lat wykrystalizowała pojęcie badania pilotażowego, aczkolwiek jest ono stosowane również w innych dziedzinach, np. w badaniach marketingowych czy rynkowych (van Teijlingen i Hundley, 2001, s. 2). Obrazuje ono trafność zastosowania takiej procedury i jej głęboki sens empiryczny jako „próby generalnej” przed badaniem właściwym. Dzięki temu ostateczne badanie może zostać dopracowane w szczegółach. Same badania pilotażowe mogą również dostarczyć materiałów empirycznych, które służą pomocą w weryfikacji wiary- 
godności wskazań badanych (Gostkowski, 1975, s. 8). Zarówno pilotaż, którego różne formy zostaną omówione poniżej, jak i badanie zasadnicze mają różne określenia - ,analiza podstawowa”, , analiza konwencjonalna”, „analiza właściwa” itp. - wszystkie one znamionują jej ostateczną, celową formę i swoiste ,przepracowanie” materiału, właśnie dzięki pilotażowi.

Jako desygnat pilotażu często spotyka się określenie „badania próbne”. Służą one także do rezygnacji z wygodnej, ale zdradliwej perspektywy „zza biurka” i sprawdzenia efektywności założonych koncepcji w terenie. Dzięki takiej praktyce zdobywa się również pewien wycinek wiedzy o podstawowych charakterystykach badanej zbiorowości, które mogą różnić się od danych zawartych w źródłach zastanych (Nowak, 2007, s. 59). Należy podkreślić, że jest to wiedza zawsze realna, a nie teoretyczna, co również przyczynia się do lepszego zrozumienia kontekstu lokalnych uwarunkowań. To z jednej strony wartość poznawcza, z drugiej jednak ,jest to próba wstępna, prowizoryczna" (Wejland, 1975, s. 77). Ten nietrwały charakter pilotażu określa istotę jego roli pomocniczej względem badania właściwego, co uwidocznione jest chociażby podczas doboru próby badawczej.

W nomenklaturze metodologii socjologicznej równie częstym określeniem badania pilotażowego jest tzw. wstępny zwiad terenowy, co z kolei przywodzi na myśl terminologię sztabową czy żołnierską (Sztumski, 1999, s. 40). Podobieństwo znaczenia pilotażu do tzw. rekonesansu obrazuje najważniejsze jego zadanie - sprawdzenie funkcjonalności w warunkach terenowych. Tylko takie działanie, czyli sprawdzenie ,jakości” narzędzia badawczego (kwestionariusza ankiety lub scenariusza wywiadu) w odniesieniu do rzeczywistych odniesień, ludzkich kapitałów poznawczych i postaw, może spowodować faktyczne ulepszenie struktury, zwiększenie przejrzystości czy klarowności badań.

W niektórych źródłach występują natomiast jeszcze inne rozróżnienia terminologiczne oddzielające sens badań rekonesansowych, pilotażowych i próbnych jako trzech odmiennych form badań wstępnych. „Badania rekonesansowe (zwiad badawczy) służą doprecyzowaniu koncepcji badawczej. Aczkolwiek podstawą koncepcji są założenia teoretyczne i wynikające z niej zapotrzebowanie na określone informacje" (Sztabiński, Sztabiński, 2005, s. 56). Ideą tego typu badań jest sprawdzenie zrozumienia przez responden- 
tów terminologii i problematyki danego projektu badawczego. Z kolei badania pilotażowe (tzw. pretest) służą przede wszystkim walidacji narzędzia badawczego, czyli kwestionariusza wraz z instrukcją ankieterską. Badane są więc przede wszystkim reakcje na pytania zawarte w kwestionariuszu, przy czym szczególnie zwraca się uwagę m.in. na zrozumiałość i drażliwość pytań, ale także kompletność i trafność instrukcji. Natomiast badania próbne odnoszą się do sprawdzenia zarówno koncepcji, jak i konkretnej operacjonalizacji wskaźników, które wynikają z przyjęcia określonej koncepcji (Sztabiński, Sztabiński, 2005, s. 56-57). Wszystkie te formy badań wstępnych opierają się zatem na odmiennych założeniach doboru respondentów, zastosowaniu zarówno metody, jak i techniki oraz czasu realizacji, ale przede wszystkim ukazują odmienne cechy badania, które można zmodyfikować pod kątem uzyskanych wyników. Co ważne, w badaniu rekonesansowym, jak również pilotażowym, mimo operowania na danych ilościowych, biorąc pod uwagę sposób opracowania wyników, sam charakter diagnozy można określić jako przeważnie jakościowy. Natomiast w badaniu próbnym o analizie, uwzględniając wskaźniki, można powiedzieć, iż jest już czysto ilościowa (Sztabiński, Sztabiński, 2005, s. 57). Na podstawie tego rozróżnienia można przyjąć, że w niniejszym tekście analiza będzie czysto pilotażowa, oparta na częstościach, czyli wskaźnikach ogólnych.

Należy w tym miejscu zaakcentować także dwie główne formy badań wstępnych: pilotaż konwencjonalny oraz pogłębiony. Pierwszy typ ma na celu tylko i wyłącznie przetestowanie narzędzia badawczego pod kątem zrozumienia jego pytań. Stosuje się w tym przypadku takie same reguły doboru jak w badaniu konwencjonalnym, tylko na nielosowej próbce, liczącej od kilku do kilkudziesięciu ankietowanych. Pilotaż pogłębiony, oprócz realizacji zadań typu konwencjonalnego, przynosi również informacje dotyczące uzyskiwania odpowiedzi istotnych oraz trafnych. Warto nadmienić, że ten typ w dużej mierze wypracowany został w tzw. łódzkiej szkole metodologii, a rozwijany był głównie przez Krystynę Lutyńską (Grzeszkiewicz-Radulska, 2012, s. 115-119). Realne zastosowanie badań pilotażowych pozwala odkryć zasadnicze kontradykcje oraz nietrafności w projektowaniu samego procesu badawczego, które mogły nie zostać wykazane w czasie konstrukcji narzędzia. 
Pilotaż pogłębiony w praktyce wdrażany jest poprzez wielowątkowe sprawdzanie narzędzia przygotowanego przez badacza, poprzez takie działania jak prowadzenie wywiadów rozszerzonych łącznie $\mathrm{z}$ obserwacją (m.in. tzw. wywiad o wywiadzie), swobodne, pozbawione ram formalnych rozmowy czy też testy psychologiczne. Uwarunkowania psychiczne respondentów oraz reakcje i procesy, jakie zachodzą u badanych po usłyszeniu pytania, również należą do arsenału środków diagnostycznych tego typu pilotażu (Lutyńska, 1984, s. 59). Co ważne, wywoływanie określonych reakcji respondentów można spożytkować nie tylko w sensie poznawczym, ale również np. terapeutycznym (Choczyński, 2018, s. 152). Do tych interakcji z badanymi w badaniu pilotażowym można dodać jeszcze jeden istotny element badania pilotażowego, jakim jest konsultacja metodologiczna, dokonywana przez badacza na potrzeby ewaluacji swojego narzędzia, a odbywana najczęściej z osobą ze specjalizacją typowo metodologiczną (Lutyńska, 1975, s. 26-27). Warto zastanowić się nad zagadnieniem tzw. wywiadu o wywiadzie, który jest poniekąd rozmową badacza $\mathrm{z}$ badanym na temat pytań kwestionariusza i reakcji na nie respondenta. Można tutaj odnaleźć takie reakcje jak: prawidłowość, trafność, istotność, jak też ich przeciwieństwa: przypadkowość, nietrafność, nieistotność. W tego typu wywiadzie mogą również pojawić się wątki natężenia drażliwości pytań (Przybyłowska, 1975, s. 457).

Po przeanalizowaniu danych z literatury przedmiotu, dotyczących aspektów badań pilotażowych, zespół badawczy postanowił pochylić się nad kwestią zrozumienia pytań przez respondentów, czyli zastosowania perspektywy pilotażu konwencjonalnego. Uzasadnieniem wyboru tej metody były przede wszystkim względy logistyczne i trudności komunikacyjne - problemy w dotarciu do respondentów przebywających na emigracji spowodowały, że w tym konkretnym przypadku uznano, że właściwą procedurą będzie skupienie się właśnie na kwestii użyteczności i funkcjonalności przekazu kierowanego do badanych. 


\section{OPIS ZAŁOŻEŃ BADANIA PILOTAŻOWEGO ŚROdOWISKA FRANCUSKIEJ POLONII}

Autorzy niniejszej publikacji wspólnie z Katarzyną Uklańską i Wojciechem Klimskim, pracownikami naukowymi Instytutu Nauk Socjologicznych Uniwersytetu Kardynała Stefana Wyszyńskiego w Warszawie (UKSW), w ramach projektu „Transmisja kulturowo-religijna w polskich parafiach i ośrodkach duszpasterskich we Francji” przeprowadzili badanie pilotażowe odnoszące się do postaw i opinii francuskiej Polonii na temat asymilacji wartości religijnych i kulturowych, w tym przede wszystkim narodowych. Zdecydowano się na przeprowadzenie badania opartego na ankiecie internetowej (elektronicznej), będącej współcześnie narzędziem najbardziej przystępnym i jednocześnie rozwojowym, rezygnując $z$ tradycyjnych form ankiet papierowych. Wykorzystano platformę LimeSurvey, która zamieszczona została na serwerze UKSW. Jest to system bazujący na architekturze kontaktu serwerrespondent, funkcjonujący pod postacią aplikacji, która zarządza programem poprzez serwer przy użyciu przeglądarki internetowej. Realizacja badania, czyli wypełnianie i przesyłanie ankiet przez respondentów, nastąpiła w okresie od września do października 2019 r. Ostatecznie próba badawcza pilotażu wyniosła $\mathrm{N}=65$ respondentów.

Nieco problematyczna okazała się kwestia dotarcia do respondentów i przekazania linku do ankiety. Biorąc pod uwagę uwarunkowania innego kraju oraz odległość geograficzną, takie przeszkody są niejako naturalne. Nawiązano w tym celu kontakt $\mathrm{z}$ polskimi księżmi pracującymi w polskich parafiach i ośrodkach duszpasterskich we Francji. Zostali oni „pośrednikami” między zespołem badawczym a potencjalnymi respondentami. Podczas nabożeństw i innych spotkań ogłaszano dostępność takiego kwestionariusza ankiety, podawano link do jej wypełnienia. Ten dobór celowy, uwarunkowany konkretnymi okolicznościami, jest dopuszczalny w tym typie badania pilotażowego, gdyż „próba nie musi odzwierciedlać struktury próby w badaniach zasadniczych, choć wskazane jest, aby wszystkie jej najważniejsze segmenty były reprezentowane" (Sztabiński, Sztabiński, 2005, s. 57). Respondenci zgłaszający się do badania zrobili to z własnej woli i dobrowolnie, gdyż chcieli przekazać swoje postawy i opinie na temat poruszanej problematyki. Biorąc 
pod uwagę cechy społeczno-demograficzne uczestników badania, można pokusić się o stwierdzenie, że zrealizowana próba, choć liczebnie ograniczona, jednak odzwierciedlała w przybliżeniu charakterystyki polskiego środowiska emigracyjnego we Francji, które jest religijnie zaangażowane.

W tym miejscu warto krótko opisać status prawny Kościoła rzymskokatolickiego we Francji, gdyż funkcjonuje on w innych uwarunkowaniach formalnych niż rozwiązania przyjęte w Polsce. Dlatego również działalność polskich parafii w tym kraju musi respektować przepisy prawa miejscowego, wywodzące się z innej tradycji legislacyjnej. Przede wszystkim należy podkreślić, że choć system francuski nie jest jednorodny, przeważa w nim koncepcja tzw. wrogiej separacji modelu państwa świeckiego, który zakłada wolność religijną, ale też zupełną separację Kościoła od państwa, ideę całkowitej świeckości instytucji państwowych i rugowanie symboliki religijnej z przestrzeni publicznej. Należy dodać, że obowiązujące przepisy, zawarte w ustawie z 1905 r., traktującej o rozdziale kościołów od państwa, pozbawiają kościoły i kościelne jednostki organizacyjne osobowości prawnej, a ich duch wywodzi się z liberalnego podejścia filozoficznego, rozwiniętego w XVIII w. i w czasach rewolucji francuskiej (Wasilewicz, 2013, s. 197-199). Taka sytuacja dotycząca statusu prawnego Kościoła rzymskokatolickiego i jego obecności w życiu społeczeństwa francuskiego może wpływać na postawy Polaków we Francji, starających się funkcjonować w innych uwarunkowaniach prawno-politycznych (Łakomy, 1999, s. 83).

Aby zapewnić sobie jeszcze lepszy odzew wśród potencjalnych uczestników badania pilotażowego, postanowiono o przekazaniu ulotek opisujących ogólną ideę badania i jednocześnie zachęcających do wzięcia w nim udziału. Materiały zostały przekazane do dwóch parafii paryskich - mieszczących się przy ulicach Saint Honoré (parafia rzymskokatolicka pw. Wniebowzięcia Najświętszej Maryi Panny) oraz Claude Lorrain (parafia polska w Paryżu pw. św. Genowefy). Trzecim miejscem był Lyon i parafia zlokalizowana przy alei Jeana Mermoza (parafia pw. Trójcy Świętej). Wybór tych miejsc uwarunkowany był przede wszystkim dostępnością znacznej liczby potencjalnych uczestników badania, gdyż wspomniane lokalizacje miejsc religijnych cieszą się dużą popularnością wśród wiernych. Pierwotny operat losowania (doboru jednostek do próby) opierał się na ok. 70 jednostkach Polskiej Misji Katolickiej we Francji. 
Stanowiły one bazę polskich parafii rzymskokatolickich oraz środowisk duszpasterskich na ziemi francuskiej. Taką próbę założono ze względu na rozmiar badania właściwego - docelowego, które miało być oparte na kwotowo-losowym doborze próby, a tym samym mieć charakter badania reprezentatywnego, z możliwością generalizacji wniosków z próby na populację.

Zastosowano narzędzie badawcze typu CAWI (ang. computer assisted web interview). Ankieta internetowa została zbudowana na bazie 43 pytań, z których 8 odnosiło się do cech społeczno-demograficznych (tzw. metryczkowych), a pozostałe (35) stanowiły sprawdzian opinii na temat kultury religijnej w połączeniu z kulturą narodową. Wśród pytań można odnaleźć klasyczne odwołania do definicji socjologii religii - pytania o stosunek do wiary i praktyk religijnych, norm teologicznych i moralności katolickiej, środowiska socjalizacyjnego parafii, łączenia wartości religijnych z ideałami patriotycznymi. Zastosowano również ciekawe uzupełnienie pytań zamkniętych poprzez zamieszczenie otwartych formularzy, gdzie respondenci mogli wyrazić swoją wiedzę o pomnikach polskich zasłużonych postaci czy miejscach związanych z wybitnymi Polakami. Dodatkowo na początku ankiety zamieszczono krótką instrukcję jej wypełniania, przeznaczoną dla respondentów. Zawarto w niej procedurę odpowiedzi, reguły przejścia pomiędzy pytaniami, akceptację odpowiedzi, możliwość ich korekty, a także zakończenie, akceptację odpowiedzi i wysłanie całości. Należy tutaj zaznaczyć, że badani zostali uczuleni na kwestię zamknięcia ankiety i w tym przypadku brak możliwości modyfikacji wskazań. Podano również numer kontaktowy do zespołu badawczego, aby można było się porozumieć w razie jakichkolwiek problemów technicznych.

\section{CECHY SPOEECZNO-DEMOGRAFICZNE RESPONDENTÓW}

Przystępując do opisu cech charakterystycznych próby badawczej, na początku należy wyróżnić strukturę wieku badanych. Najliczniej reprezentowane są osoby w wieku 35-44 lata $(33,9 \%)$, natomiast najmniej odnotowano osób najstarszych (powyżej 65 lat) i najmłodszych (do 24 lat) - po 3,6\% wskazań. Pozostałe kategorie wieku prezentują się następująco: 55-64 lata - 26,8\%, 45-54 lata - 19,6\%, 25-34 lata - 12,5\%. Pilotażowa próba 
badawcza jest silnie sfeminizowana. Kobiety zdecydowanie przeważają nad mężczyznami (85,7 vs 14,3\%). Z kolei deklaracje na temat stanu cywilnego pokazują, że zdecydowana większość ankietowanych pozostaje w związku małżeńskim (62,5\%). Znacznie mniej jest osób stanu wolnego - panien i kawalerów - 16,1\%. Stan wdowieństwa podało $12,5 \%$ badanych, natomiast rozwodnicy reprezentowani są na poziomie 5,4\%. Najmniej uczestników badania zadeklarowało pozostawanie w związkach partnerskich i konkubinatach $(3,6 \%)$.

Po poznaniu podstawowych uwarunkowań cech społeczno-demograficznych (wiek, płeć, stan cywilny) należy także przedstawić kolejne opisy, tym razem odnoszące się bardziej do struktury społecznej, w jakiej funkcjonują badani. Największa liczba uczestników badania deklaruje wykształcenie wyższe magisterskie (42,9\%), a dwa razy mniej osób wykazało średni jego poziom (ukończone liceum lub technikum - 21,4\%). Wykształcenie policealne lub pomaturalne wskazało 16,1\% ogółu badanych, a wyższe licencjackie lub inżynierskie 14,3\%. Najmniej respondentów zadeklarowało wykształcenie zawodowe $(5,4 \%)$. Jeśli chodzi o sytuację zawodową, należy zaznaczyć, że większość ankietowanych była zatrudniona (64,3\%), a bezrobocie zadeklarowało jedynie $5,4 \%$ osób. Więcej niż co dziesiąty badany określił się jako emeryt (12,5\%), natomiast rencistów było znacznie mniej (3,6\%), tak samo jak uczniów lub studentów (1,8\%). Zastanawiać może dość wysoki wskaźnik braku odpowiedzi (12,5\%), co może być spowodowane chęcią ukrycia wstydliwego dla badanych faktu nieposiadania pracy lub wykonywania jej w szarej strefie. Respondenci mieli także do wyboru odpowiedź „inne”. Skorzystały z niej tylko cztery osoby, wskazując takie zajęcia jak: macierzyństwo domowe, opieka nad dzieckiem, urlop macierzyński oraz ogólnie wychowywanie dzieci.

Brak odpowiedzi był powszechniejszy przy okazji szczegółowej odpowiedzi na pytanie o rodzaj pracy zawodowej. W tym wypadku aż $28,6 \%$ respondentów jej nie udzieliło. Potwierdza to przypuszczenia o drażliwości tego rodzaju pytania dla przedstawicieli Polonii francuskiej. Poza tym najczęściej badani wskazywali pracę w usługach $(16,1 \%)$, proste prace najemne, np. sprzątanie $(14,3 \%)$, czy też pracę urzędniczą lub nauczycielską (oba wskazania po 10,7\%). Mniej wskazań dotyczyło pracy w korporacji $(8,9 \%)$ oraz pracy w gospodarstwie domowym, pracy eksperckiej oraz profesji robotniczej (we wszystkich trzech 
przypadkach po 3,6\% wskazań). Oprócz tych konwencjonalnych odpowiedzi dotyczących zawodów badani pojedynczo wskazali także inne zajęcia: pracę artystyczną, pracę w bibliotece oraz w służbie zdrowia.

Dominującym miejscem zamieszkania respondentów jest wielkie miasto powyżej 500 tys. mieszkańców (33,9\% odpowiedzi). Drugą najliczniejszą grupę stanowią osoby mieszkające w małych miastach do 20 tys. mieszkańców (23,2\%). W miastach średnich (zarówno tych liczących 20-49 tys., jak i 50-99 tys. mieszkańców) zamieszkuje po $12,5 \%$ ankietowanych. Natomiast odsetek osób deklarujących zamieszkanie na wsi i w miastach dużych (100499 tys. mieszkańców) wynosi po 8,9\%. Uzupełnieniem tych danych są wskazania dotyczące czasu trwania emigracji: 44,6\% ogółu badanych podało, że przebywają poza granicami kraju ojczystego powyżej 21 lat, okres 16-20 lat oraz 6-10 lat podało po $16,1 \%$ ankietowanych, dla $14,3 \%$ osób jest to $11-15$ lat, natomiast $8,9 \%$ wskazało okres do 5 lat.

\section{DIAGNOZA EFEKTYWNOŚCI I ZROZUMIENIA PYTAŃ PILOTAŻU}

Po naszkicowaniu ogólnego oglądu próby badawczej pod kątem cech społeczno-demograficznych pora przystąpić do analizy ankiety pilotażowej w odniesieniu do funkcji pilotażu konwencjonalnego, czyli zrozumienia pytań kwestionariusza. Wiele uwagi w tego typu analizach poświęca się odpowiedziom typu „nie wiem” oraz brakowi odpowiedzi. Problematyka ta znalazła się w kręgu zainteresowań chociażby Johna Galtunga (Lutyńska, 1975, s. 17). Te dwa wskaźniki pokazują w przybliżeniu, jak duża jest drażliwość bądź niezrozumienie pytania, i skłaniają de refleksji, w jaki sposób je poprawić.

Innym ważnym aspektem diagnozy jakości narzędzia badawczego, a szczególnie ankiety, jest rzetelne podejście do instrukcji i reguły przejść między pytaniami. Te techniczne przejścia, warunkujące np. pomijanie konkretnych pytań i przechodzenie do innych, są bardzo narażone na brak adekwatnej informacji, nieprzemyślenie, brak planowania i chaotyczność. Takie niedopatrzenie może z kolei spowodować własną inicjatywę respondenta, brak zdyscyplinowania i niechęć do podporządkowania się (Sztabiński, 1982, s. 134). W skrajnych wypadkach złe rozplanowanie przejść między pytaniami i/lub 
brak instrukcji może całkowicie zniweczyć trud badawczy, gdyż narzędzie nasycone jest kontaminacjami wpływającymi na wynik końcowy.

Waga staranności opracowania pytań jest pierwszorzędna w odniesieniu do planowania całego procesu badawczego. W tym przypadku można odnieść się do błędów związanych z samą konstrukcją narzędzia, takich jak zła kolejność pytań, zbyt duża ich liczba, niedopasowanie, nieodpowiednie pogrupowanie, zaniechanie tzw. pytań metryczkowych. Z kolei kontaminacje związane $\mathrm{z}$ treścią pytań można rozpatrywać pod kątem ich niezrozumienia (co przyczynia się do błędnego odczytania intencji badacza), długości, skomplikowania, braku ścisłości znaczenia, sugerowania odpowiedzi, powtarzania, występowania określeń żargonowych czy specjalistycznych, tendencyjności, wieloznaczności, wieloskładnikowych odniesień, a także błędów skalowania i braku pytań kontrolnych (Kolny, 1997, s. 34). Podniesione „techniczne” aspekty potencjalnych błędów w konstrukcji narzędzia badawczego będą zasadniczą podstawą poniższych odniesień do rzeczywistego narzędzia badawczego.

Patrząc przekrojowo na cały kwestionariusz ankiety zastosowanej w niniejszym badaniu, można wyodrębnić trzy rodzaje częstotliwości odpowiadania na pytania przez respondentów: odpowiedź całościowa (praktycznie cała próba, czyli 65 badanych, udzieliła odpowiedzi), niemal całościowa (odpowiedzi nie udzieliło maksymalnie 10 osób na całą próbę) oraz mniejszościowa (większość lub znaczna część osób z próby nie odpowiedziała na pytania zamieszczone w ankiecie). Na taki stan rzeczy składa się kilka czynników natury poznawczej, reguły przejścia między pytaniami, instrukcja kwestionariusza ankiety oraz w mniejszym stopniu oddziaływanie konkretnego światopoglądu. Podstawowe znaczenie miało w tym wypadku także pewne znużenie kwestionariuszem i coraz mniejsza chęć jego wypełniania. Potwierdzeniem tego jest narastanie braków odpowiedzi na końcowe pytania.

Co istotne, pytania obrazujące klasyczne odniesienia do kategorii socjoreligijnych, takie jak stosunek do wiary i praktyk religijnych (np. ,jak często się Pan(i) spowiada?”; ,jak często przystępuje Pan(i) do komunii św.?”), odniesienia do moralności chrześcijańskiej i katolickiej (np. „czy według Pana(i) dopuszczalne są takie zachowania jak eutanazja, zmiana płci, aborcja, zdrada małżeńska, rozwód?"), sposoby pogłębiania swojej wiary (np. „w jaki sposób pogłębia Pan(i) swoją wiarę? - uczestniczę w pielgrzymkach do miejsc kultu religijnego; 
rozmawiam z księżmi na tematy religijne”), uzyskiwały niemal zawsze pełną pulę odpowiedzi. Świadczy to o zrozumieniu pytań, które są stosowane w sposób uniwersalny w obszarze polskiej socjologii religii, a wprowadzone zostały do użytku przez znamienitych metodologów, takich jak Władysław Piwowarski. Ich zastosowanie było zatem ze wszech miar właściwe.

Inaczej wygląda sytuacja $\mathrm{z}$ danymi przy rozkładzie odpowiedzi na pytania dotyczące katechezy organizowanej w danej parafii, a wynika to z faktu samej konstrukcji narzędzia, a nie z umyślnego uchylania się respondentów od odpowiedzi. W pierwszym pytaniu dotyczącym tej kwestii (pytanie 13) zastosowano opcję odpowiedzi wariantowej, która kierowała lub nie (w zależności od rodzaju odpowiedzi) do następnych pytań. Kolejne pytanie (14) przeznaczone było tylko dla respondentów, którzy wcześniej zaanonsowali brak swojego uczestnictwa w katechezach z powodu osobistego wyboru. Ogólnie 7 wariantów odpowiedzi tego pytania (typu zamkniętego) wskazały łącznie 23 osoby, a nie wskazały 42, czyli wystąpiła identyczna proporcja jak we wstępnym pytaniu kierującym. W przytoczonym pytaniu kierującym (pytanie 13) uwzględniono również przypadek, w którym respondenci nie uczęszczają na katechezy, gdyż nie są one w ogóle formalnie organizowane. Wspomniane warianty odpowiedzi potwierdzających w pytaniu 14 („Dlaczego nie uczęszcza Pan(i) na katechezy prowadzone w swojej macierzystej parafii?”) uzyskały następującą kolejność pod względem skali wyboru: „samodzielnie pogłębiam wiedzę religijną" (73,9\%); „nie mam czasu” (65,2\%); „dotarcie do parafii zajmuje mi zbyt wiele czasu” (47,8\%); "nie odpowiadają mi terminy tych katechez” $(34,8 \%)$; „tematyka katechez jest przedstawiana na niskim poziomie” $(26,1 \%)$; „nie interesuje mnie tematyka tych katechez” (21,7\%); ,jestem w konflikcie z księżmi pracującymi w macierzystej parafii” (4,3\%). Widać więc, że mimo ograniczonej próby badawczej wyniki i proporcje wskazują na właściwy zapis pytania, jego sens i odczytanie przez respondentów, a odpowiedzi prezentują logiczny ciąg przyczyny i skutku. Oprócz zrozumiałości języka polecenia w tym wypadku pomógł także techniczny zapis narzędzia badawczego w formacie CAWI, dzięki intuicyjnemu interfejsowi (który np. uniemożliwiał podwójne lub sprzeczne odpowiedzi) oraz formule automatycznego kierowania do określonego pytania po wybraniu danego wariantu odpowiedzi. Reguły przejścia były zatem zastosowane poprawnie. 
Następną tego typu prawidłowość można dostrzec przy analizie pytania dotyczącego traktowania danej parafii jako swojej (pytanie 17). Do wyboru była m.in. odpowiedź „parafia polska”. Jej wybór prowadził badanego do następnego pytania (18), dotyczącego motywów kierujących respondentem, który uznał polską parafię za swoją. Wśród nich można wymienić w kolejności - „liturgia jest w języku polskim” (100\%); „cenię księży pracujących w tej parafii” (95,5\%); „atrakcyjny sposób przekazu wiary (treść kazań)” $(86,4 \%)$; „możliwość spotkania z rodakami i znajomymi” (86,4\%); „możliwość lepszego zaangażowania się w życie parafii” (70,5\%); „oferta kulturalna parafii” (63,6\%); „oferta liturgiczno-katechetyczna parafii” $(61,4 \%)$; odpowiedzi na te pytania udzieliły 44 osoby, tzn. tyle, ile wskazało polską parafię, a więc pozostali respondenci (21 osób) nie udzieli odpowiedzi na pytanie o motywy takiego wyboru.

Natomiast najwięcej braków danych odnotowano w innym pytaniu wariantowym: „Dlaczego zazwyczaj chodzi Pan(i) na msze św. do kościoła (kościołów) poza Pana(i) parafią?" (pytanie 19). Tylko jedna osoba z próby badawczej udzieliła odpowiedzi na to pytanie. Aczkolwiek trzeba podkreślić, że jest to wynikiem wyboru tej opcji tylko przez tę jedną osobę - pozostali nie mieli możliwości, aby odpowiedzieć na to pytanie. W tym wypadku również zadziałał system przekierowania respondenta, który został zastosowany w pytaniu 17. Jedyny badany, który wybrał w nim opcję „inna parafia francuska”, został automatycznie skierowany do pytania 19 . W tym wypadku również reguły przejścia zadziałały prawidłowo.

Pośrednią częstotliwość odpowiedzi respondentów na pytania ankiety (czyli maksymalnie 10 przypadków braku odpowiedzi) daje się zauważyć praktycznie od połowy ankiety (gdy uwzględni się w niej tzw. pytania metryczkowe). Jest to pytanie 20, brzmiące: „Kto według Pana(i) powinien być przede wszystkim odpowiedzialny za funkcjonowanie parafii?”. Brakuje tutaj jednej odpowiedzi. Taka sama obserwacja braku pojedynczej odpowiedzi widoczna jest w pytaniach: „Kto w Pana(i) parafii podejmuje decyzje dotyczące jej funkcjonowania?”; „Czy uważa Pan(i), że ma wpływ na sprawy parafii?”. Co ważne, w miarę pojawiania się kolejnych pytań widać tendencję wzrostową braku odpowiedzi. Nie są to jednak duże przyrosty, a raczej jednostkowe. Brak dwóch wypowiedzi widoczny jest w pyta- 
niach poruszających kwestie zaangażowania w działalności parafii, a dalej - przechodząc do innych znaczeniowo segmentów kwestionariusza - stosunku do polskości.

W tym segmencie od pytania dotyczącego przejawów patriotyzmu „w okazaniu szacunku dla polskiego godła, polskiej flagi, polskiego hymnu narodowego" brak odpowiedzi wzrasta - nie udzieliły jej trzy na 65 osób uczestniczących w badaniu. Brak sześciu odpowiedzi odnotowano z kolei od pytania obrazującego podejmowanie konkretnych działań na rzecz wspierania polskości, określonych jako „aktywne działania w organizacjach polonijnych”. Warto zaznaczyć ciekawą obserwację - z katalogu dostępnych opcji w tym pytaniu jedna uzyskała komplet wskazań (65) - było nią „wspieranie materialnie Polaków mieszkających w Polsce”, co obrazuje ważność tego rodzaju troski emigrantów. Siedem osób nie udziela odpowiedzi od następnego pytania (pytanie 28), które odnosi się do organizowania w parafiach inicjatyw, które są związane z polska kulturą. Kolejna strata wskazania (8 braków) widoczna jest od następnego, 29 pytania: „Jaki jest Pan(i) stosunek do przekazu wartości patriotycznych w parafii?”. Dziewięć braków odpowiedzi odnotowano przy końcowych pytaniach otwartych dotyczących wiedzy o pomnikach ważnych dla polskiego narodu, sławnych Polaków działających we Francji, troski o polskie pomniki na ziemi francuskiej, wskazywania ich innym Polakom lub turystom czy też wiedzy na temat mało popularnych miejsc czy pomników związanych z Polską. Tyle samo braków odpowiedzi dostrzeżono w pytaniach metryczkowych.

$\mathrm{Na}$ koniec analizy warto zwrócić uwagę na jedno z pytań, w którym potencjalnie doszło do niezrozumienia intencji badawczych. Odnosi się to do sformułowania „uczestniczę w praktykach religijnych” jako jednej z opcji odpowiedzi na pytanie 23, dotyczące sposobów zaangażowania w parafii. Uzyskane wyniki w porównaniu z liczbą wskazań dla innych opcji, zwłaszcza „składam ofiary na tacę”, mogło być odczytane jako dodatkowe praktyki poza udziałem w mszach św. i nabożeństwach lub też pomoc w ich organizacji czy też przebiegu samej liturgii. Sformułowanie tej konkretnej opcji wyboru powinno zostać ponownie przedyskutowane jako wyrażenie zbyt pojemne treściowo, a co za tym idzie - wieloznaczne i nieprecyzyjne. 


\section{Podsumowanie}

Po analizie rozkładu odpowiedzi na pytania można zauważyć, że są one zazwyczaj ściśle związane z rodzajem pytań wariantowych, a nie z konkretną treścią i rodzajem uzyskiwanej informacji. Można więc stwierdzić wstępnie, że koncept doboru pytań, kompozycja narzędzia badawczego były w większości właściwe, optymalne dla badanej próby. Natomiast przyczyną stopniowego pojawiania się większej liczby braków odpowiedzi może być znużenie samą sytuacją badania, konieczność poświęcenia na nie większej ilości czasu od zaplanowanej na ten cel. Nie zauważono jednak, aby ten brak danych zwiększał się w niepokojącym tempie, jest on raczej naturalny dla budowy kwestionariusza ankiety tego typu. Wieloznaczność i nieprecyzyjność udało się zdiagnozować w jednym pytaniu dotyczącym praktyk religijnych.

Dane pochodzące z niniejszej analizy i rozpatrywane pod kątem pilotażu konwencjonalnego na pewno obrazują doniosłość przeprowadzenia próby generalnej przed badaniem właściwym. Oprócz oczywistych korzyści, wymienionych zresztą w literaturze przedmiotu, w tym konkretnym badaniu pilotaż wykazał przede wszystkim stopień znużenia badanych czasem trwania badania (wypełniania ankiety) przy równoczesnym raczej metodologicznie poprawnie skonstruowanym kwestionariuszu. Należy zwrócić uwagę na logiczną spójność narzędzia, jak również przeważnie występującą adekwatność użytego języka. Nie odnotowano również wielu sytuacji nieudzielania odpowiedzi ze względu na drażliwość danych (z wyjątkiem pytania o rodzaj wykonywanej pracy), co z kolei świadczy o właściwym doborze zakresu informacji o postawach ankietowanych, a tym samym o poszanowaniu ich wrażliwości i godności. Taka praktyka jest współcześnie akcentowana w wytycznych i kodeksach postępowania zespołów badawczych wobec uczestników projektów. Natomiast sfera pozyskiwania środków materialnych z pracy zawodowej okazała się tą, której część badanych nie ujawniła, prawdopodobnie z powodu negatywnego stosun$\mathrm{ku}$ do niej i niezadowolenia $\mathrm{z}$ rodzaju zarobkowania, niezgodnego z zamiarami.

Wysiłki zespołu badawczego powinny zostać zogniskowane przede wszystkim na kwestii dostępności respondentów, tak aby w badaniu zasadniczym udało się skompletować założoną próbę badawczą, która spełniać będzie warunki statystycznej reprezentatywności. Oprócz wykazania jednego 
pytania $\mathrm{z}$ widoczną wieloznacznością językową należy także zastanowić się nad pytaniami otwartymi, które w niniejszym badaniu pełniły rolę pewnego kontrapunktu i sprawdzenia wiedzy badanych o polskim dziedzictwie kulturowym we Francji.

Podsumowując, niniejsze badanie pilotażowe spełniło swoją rolę i jako takie stanowi dobry punkt wyjścia zarówno do przeprowadzenia pilotażu pogłębionego, jak i badań zasadniczych. Badanie może stanowić uzupełnienie najnowszych pozycji naukowych zajmujących się tematyką istoty i roli parafii w środowiskach wiernych (Wysocki, 2018, s. 411), czy także ogólnych prac dotyczących studiów migracyjnych (Romaniszyn, 2015, s. 17-18) lub środowisk polonijnych (Walewander, 2015, s. 32-33). Przede wszystkim udało się uzyskać reakcję respondentów na zaproponowaną tematykę badawczą, co pokazuje trafność jej wdrożenia w ten konkretny obszar społecznej rzeczywistości. Samo testowanie narzędzia badawczego uwrażliwiło jego twórców na konieczność przykładania jeszcze większej wagi do opracowywania pytań, zadbania o ich metodologiczną rzetelność oraz empiryczną trafność. Przede wszystkim w analizie przekazu kultury polskiej w parafiach francuskich udało się połączyć założenia właściwej konstrukcji narzędzia badawczego $\mathrm{z}$ adekwatnością tej konkretnej tematyki postaw do polskości w warunkach emigracyjnych.

\section{Bibliografia}

Choczyński, M. (2018). Quasi-terapeutyczna funkcja wywiadu częściowo ustrukturyzowanego $w$ odniesieniu do badań własnych. Rola i znaczenie dobrej relacji $w$ wywiadzie socjologicznym, „Przegląd Socjologii Jakościowej”, nr 14/4, s. 150-170. ISSN 1733-8069.

Dubisz, S. (2003a). Pilot. W: S. Dubisz (red.), Uniwersalny słownik języka polskiego, t. 3 (P-S), wyd. 1, Warszawa: Wydawnictwo Naukowe PWN, s. 142. ISBN 8301138688.

Dubisz, S. (2003b). Pilotaż. W: S. Dubisz (red.), Uniwersalny słownik języka polskiego, t. 3 (P-S), wyd. 1, Warszawa: Wydawnictwo Naukowe PWN, s. 142-143. ISBN 8301138688.

Gostkowski, Z. (1975). Wstęp. W: Z. Gostkowski, J. Lutyński (red.), Analizy i próby technik badawczych $w$ socjologii, t. 5: Studia pilotażowe i analizy weryfikacyjne, Wrocław-Warszawa-Kraków-Gdańsk: Ossolineum, s. 5-11. 
Grzeszkiewicz-Radulska, K. (2012). Metody badań pilotażowych, „Acta Universitatis Lodziensis. Folia Sociologica”, nr 42, s. 113-141. ISSN 2353-4850.

Kolny, B. (1997). Czemu służą badania pilotażowe?, „Marketing i Rynek”, nr 5, s. 33-34. ISSN 1231-7853.

Lutyńska, K. (1975). Pilotaż „pogłębiony”. W: Z. Gostkowski i J. Lutyński (red.), Analizy i próby technik badawczych $w$ socjologii, t. 5: Studia pilotażowe i analizy weryfikacyjne, Wrocław-Warszawa-Kraków-Gdańsk, Ossolineum, s. 13-75.

Lutyńska, K. (1984). Wywiad kwestionariuszowy. Przygotowanie i sprawdzenie narzędzia badawczego, Wrocław-Warszawa-Kraków-Gdańsk-Łódź, Ossolineum, IFiS PAN.

Łakomy, H. (1999). Państwo a Kościót we Francji. Historia i współczesność, Kraków: Wydawnictwo Naukowe WSP. ISBN 838751344X.

Nowak, S. (2007). Metodologia badań społecznych, Warszawa: Wydawnictwo Naukowe PWN. ISBN 9788301149994.

Przeworski, A. (1966). Niektóre metody oceny pilotażu, „Studia Socjologiczne”, nr 2/21, s. 277-291. ISSN 0039-3371.

Przybyłowska, I. (1975). Wywiad o wywiadzie jako metoda otrzymywania informacji o reakcji wewnętrznej respondenta na pytanie kwestionariusza. W: Z. Gostkowski i J. Lutyński (red.), Analizy i próby technik badawczych w socjologii, t. 5: Studia pilotażowe i analizy weryfikacyjne, Wrocław-Warszawa-Kraków-Gdańsk, Ossolineum, s. 457-488.

Romaniszyn, K. (2015). Badania migracyjne - dorobek i nowe wyzwania. W: S. Zych i B. Walicki (red.), W kręgu badań nad Polonia i duszpasterstwem polonijnym. Istota i metodologia, Lublin: Ośrodek Badań nad Polonią i Duszpasterstwem Polonijnym KUL, s. 11-29. ISBN 9788392748373.

Smith, C.A. (2019). The uses of pilot studies in sociology: a processual understanding of preliminary research, „American Sociologist”, No. 50, s. 589-607. ISSN 0003-1232.

Sztabiński, F. (1982). Ankieta i jej pilotaż. W: Z. Gostkowski (red.), Z metodologii $i$ metodyki socjologicznych badań terenowych, z. 7, Warszawa: Wydawnictwo IFiS PAN, s. 103-136.

Sztabiński, P.B., Sztabiński, F. (2005). Jak połączý pilotaż z badaniem próbnym? Przykład Europejskiego Sondażu Społecznego 2004, „ASK: Społeczeństwo, Badania, Metody", nr 14, s. 55-75.

Sztumski, J. (1999). Wstęp do metod i technik badań społecznych, wyd. 5 zmienione i uzupełnione, Katowice: Wydawnictwo Naukowe „Śląsk”. ISBN 8371641443. 
Teijlingen, E.R. van i Hundley, V. (2001). The importance of pilot studies, „Social Research Update", No. 35, s. 1-4. ISSN 2398-1547.

Walewander, E. (2015). Badania nad Poloniq - wczoraj i dziś. Niektóre aspekty problematyki polonijnej. W: S. Zych i B. Walicki (red.), W kreggu badań nad Poloniq i duszpasterstwem polonijnym. Istota i metodologia, Lublin: Ośrodek Badań nad Polonią i Duszpasterstwem Polonijnym KUL, s. 31-38. ISBN 9788392748373.

Wasilewicz, U. (2013), Organizacja funkcjonowania Kościoła we francuskim porzadku prawnym. Zarys problematyki, „Kościół i Prawo”, nr 2/15, s. 197-208. ISSN 02087928.

Wejland, A.P. (1975). Pilotaż. Szkic pojęcia. W: Z. Gostkowski i J. Lutyński (red.), Analizy i próby technik badawczych $w$ socjologii, t. 5: Studia pilotażowe i analizy weryfikacyjne, Wrocław-Warszawa-Kraków-Gdańsk, Ossolineum, s. 77-93.

Wysocki, A. (2018). Dynamika zmian w parafii a jej elementy istotne. Śladami pioniera socjologii parafi ks. Franciszka Mirka, Warszawa: Wydawnictwo Naukowe UKSW. ISBN 9788380904750. 
